Verena Walter

Lebenszykluskosten Laborgebäude 


\section{Schriftenreihe Bauökonomie}

herausgegeben von

Prof. Dr. Christian Stoy

Band 7 
Verena Walter

\section{Lebenszykluskosten Laborgebäude}

Entwicklung eines Werkzeugs zur projektspezifischen Kostenermittlung 
Dissertation, University of Stuttgart (D 93), 2020

ISBN 978-3-11-068612-8

e-ISBN (PDF) 978-3-11-068622-7

e-ISBN (EPUB) 978-3-11-068631-9

Library of Congress Control Number: 2021938803

Bibliografische Information der Deutschen Nationalbibliothek

Die Deutsche Nationalbibliothek verzeichnet diese Publikation in der Deutschen Nationalbibliografie; detaillierte bibliografische Daten sind im Internet über http://dnb.dnb.de abrufbar.

(C) 2021 Walter de Gruyter GmbH, Berlin/Boston

Druck und Bindung: $\mathrm{CPI}$ books $\mathrm{GmbH}$, Leck

www.degruyter.com 